\title{
REGENERASI DAN PERBANYAKAN RUMPUT LAUT Kappaphycus alvarezii HASIL TRANSFORMASI GEN SUPEROKSIDA DISMUTASE (MaSOD)
}

\author{
Emma Suryati*\#, Hidayah Triana**), Utut Widyastuti**), dan Andi Tenriulo*) \\ *) Balai Penelitian dan Pengembangan Budidaya Air Payau \\ *) Fakultas Perikanan dan Kelautan, Universita Muslim Indonesia \\ **) Pusat Penelitian Sumberdaya Hayati dan Bioteknologi dan Departemen Biologi, Fakultas Matematika dan IImu \\ Pengetahuan Alam, Institut Pertanian Bogor
}

\begin{abstract}
ABSTRAK
Transformasi gen superoxide dismutase (MaSOD) pada rumput laut Kappaphycus alvarezii menggunakan Agrobacterium tumefacient telah dilakukan secara in vitro. Transformasi gen MaSOD ke dalam genom rumput laut diharapkan dapat mengurangi cekaman oksidatif terutama yang disebabkan oleh perubahan suhu, salinitas, dan cemaran logam di perairan. Penelitian ini bertujuan untuk regenerasi rumput laut hasil introduksi gen MaSOD dan non-transgenik pada labu kultur. Regenerasi dan perbanyakan rumput laut hasil transformasi gen MaSOD dilakukan di laboratorium pada labu kultur yang diletakkan dalam "culture chamber" yang dilengkapi dengan aerasi menggunakan media kultur yang diperkaya dengan pupuk PES, Grund, Conwy, dan SSW sebagai kontrol, salinitas 20, 25, 30, 35, dan $40 \mathrm{~g} / \mathrm{L}$, pH 4, 5, 6, 7, dan 8. Intensitas cahaya antara 500-2.000 lux dengan fotoperiode terang dan gelap 8:16; 12:12; dan 16:8. Untuk merangsang pertumbuhan eksplan dilakukan pemeliharaan dengan penambahan hormon tumbuh IAA dan BAP dengan perbandingan 1:1, 1:2, dan 2:1. Penelitian dilakukan secara bertahap. Evaluasi transgenik dilakukan menggunakan teknik PCR. Hasil penelitian memperlihatkan bahwa sintasan yang paling tinggi diperoleh menggunakan media PES (94\%), salinitas $30 \mathrm{~g} / \mathrm{L}(90 \%), \mathrm{pH} 7(96 \%)$, intensitas cahaya pada 1.500 lux $(80 \%)$, fotoperiode $12: 12(84 \%)$, komposisi ZPT dengan campuran IAA dan BAP dengan perbandingan 2:1. Hasil analisis PCR memperlihatkan K. alvarezii transgenik putatif mengandung transgen MaSOD sebanyak $78 \%$ dari hasil transformasi.
\end{abstract}

KATA KUNCI: regenerasi; Kappaphycus alvarezii; gen MaSOD; cekaman lingkungan

ABSTRACT: Regeneration and multiplication of seaweed Kappaphycus alvarezii transformed Superoxide dismutase (MaSOD) gene. By: Emma Suryati, Hidayah Triana, Utut Widyastuti, and Andi Tenriulo

Superoxide dismutase transformation (M aSOD) gene of seaweed Kappaphycus alvarezii mediated by Agrobacterium tumefacient has been successfully done in vitro. MaSOD genes introduced into the seaweed genome is expected to reduce oxidative stress caused by environmental conditions such as changes in temperature, salinity and metal contamination of the water. This study aimed to regenerate both the MaSOD transformed seaweed and non-transgenic in a culture flask. Regeneration and multiplication of those seaweed were conducted in a laboratory flask cultures placed in a "culture chamber" which was aerated and enriched with fertilizers PES, Grund, Conwy, and SSW as a control, salinity $20,25,30,35$, and $40 \mathrm{~g} / \mathrm{L}, \mathrm{pH}: 4,5,6,7$, and 8 . the light intensity between 500-2000 lux, with light and dark photoperiod 8:16; 12:12; and 16:8. To stimulate the growth of explants the addition of growth hormone IAA and BAP with ratios of 1:1, 1:2 and 2:1 were performed. This study was a multiple-step of process, by which transgenic explants was identified by PCR method. The results showed that the highest survival ratewas obtained using media PES $(94 \%)$, salinity $30 \mathrm{~g} / \mathrm{L}(90 \%), \mathrm{pH}=7(96 \%)$, the intensity of light at 1500 lux $(80 \%)$, photoperiod $=12: 12$ $(84 \%$, and ratio of IAA and BAP 2: 1 . The results of PCR analysis showed the putative $K$. alvarezii transgenic MaSOD was $78 \%$ of explants.

\section{KEYWORDS: regeneration; Kappaphycus alvarezii; MaSOD genes; environmental stress}

\footnotetext{
\# Korespondensi: Balai Penelitian dan Pengembangan Budidaya

Air Payau. Jl. Makmur Dg. Sitakka No. 129, Maros 90512,

Sulawesi Selatan, Indonesia. Tel. + (0411) 371544

E-mail: emmasuryati@ yahoo.com
} 


\section{PENDAHULUAN}

Rumput laut K. alvarezii merupakan salah satu komoditas unggulan penghasil karaginan yang banyak dimanfaatkan dalam industri kertas, tekstil, fotografi, pasta, dan pengalengan ikan. Budidaya K. alvarezii mampu menjadi kunci pemberdayaan masyarakat pesisir, peningkatan usaha budidaya di tingkat petani memacu peningkatan sediaan benih unggul baik kualitas maupun kuantitasnya. Selain itu, permintaan pasar dunia masih sangat tinggi (Collen,1995; FAO, 2010).

Kendala yang sering dihadapi pembudidaya dalam rangka peningkatan produksi adalah terbatasnya ketersediaan bibit yang berkualitas tinggi, lemahnya ketahanan terhadap penyakit ice-ice, serta kurangnya ketahanan terhadap cekaman lingkungan biotik maupun abiotik yang sering terjangkit pada lahan budidaya. Ketersediaan bibit yang berkualitas baik sangat dipengaruhi oleh musim, salinitas, suhu, intensitas cahaya, serta kondisi lingkungan perairan yang digunakan untuk membudidayakan rumput laut (Yulianto \& Mira, 2009; Mamboya, 2007).

Dalam rangka meningkatkan dan mempertahankan produksi rumput laut nasional perlu dilakukan upayaupaya untuk mengatasi permasalahan pada budidaya, antara lain menurunnya mutu genetik rumput laut yang disebabkan adanya serangan penyakit, serta perubahan mutu lingkungan yang ekstrem (Largo et al., 1997; Vairappan, 2006). Upaya yang dilakukan antara lain melalui pola tanam, teknik budidaya, dan penyediaan bibit yang baik antara lain kultur jaringan, serta pendekatan teknologi biomolekuler yaitu rekayasa genetik melalui transformasi gen potensial yang dapat meningkatkan ketahanan, serta memperbaiki gen dari rumput laut (Cheney et al., 2000). Beberapa peneliti telah menggunakan Agrobacterium tumeficiencens sebagai perantara transformasi, seperti yang dilakukan oleh Cheng et al. (2011).

Perbaikan mutu genetik pada rumput laut telah dirintis sejak tahun 2010 melalui kerja sama penelitian antara Balai Penelitian dan Pengembangan Budidaya Air Payau (BPPBAP), Maros dengan Pusat Antar Universitas, Institut Pertanian Bogor (PAU-IPB). Informasi yang diperoleh antara lain lain introduksi gen GFP di bawah regulasi promoter sehingga menghasilkan transgenik rumput laut sampai tahap filamen (Rajamuddin et al., 2014), kloning gen penyandi karaginan, merakit vektor ekspresi, serta introduksi gen karaginan rumput laut K. alvarezii (Rajamuddin et al., 2016), serta transformasi gen lain untuk meningkatkan ketahanan terhadap cekaman lingkungan antara lain gen PaCS (Daud et al., 2013;
Suryati et al., 2014), gen lisozim (Handayani et al., 2014), gen methalothionin type-II (Mamt2) (Fajriah et al., 2015; Suryati et al., 2015).

Transformasi gen superoksida dismutase (MaSOD) pada rumput laut $\mathrm{K}$. alvarezii telah berhasil dilakukan melalui mediasi menggunakan bakteri Agrobacterium tumefaciens, serta dapat terintegrasi pada plantet dan anakan rumput laut K. alvarezii (Triana et al., 2016). Namun regenerasi rumput laut hasil transformasi ini belum berhasil tumbuh dengan baik di laboratorium, maupun aklimatisasi pada labu kultur dan bak resirkulasi.

Kematian eksplan hasil transformasi gen sering terjadi pada pada tahap aklimatisasi pada labu kultur maupun pada bak resirkulasi. Beberapa parameter yang berpengaruh terhadap sintasan rumput laut antara lain salnitas, pH, penetrasi cahaya, rasio gelap terang, pupuk, serta kombinasi zat pemacu tumbuh (ZPT) yang diperlukan dalam pertumbuhan rumput laut (Suryati et al., 2015). Penelitian ini bertujuan untuk melakukan regenerasi rumput laut hasil transformasi gen MaSOD pada rumput laut K. alvaezii dan rumput laut nontransgenik pada media kultur yang diperkaya dengan pupuk dan komposisi ZPT yang berbeda.

\section{BAHAN DAN METODE}

\section{Transformasi dan Kokultivasi}

Rumput laut yang digunakan untuk transformasi gen MaSOD merupakan rumput laut hasil seleksi yang diperoleh dari Kabupaten Takalar, Sulawesi Selatan. Riset dilakukan di Laboratorium Balai Penelitian dan Pengembangan Budidaya Air Payau, Maros.

Transformasi gen MaSOD pada rumput laut K. alvarezii dilakukan mengikuti metode Cheney (2000). Metode transformasi dilakukan dengan mediasi Agrobacterium LB 4404 yang membawa vektor ekspresi pGWB5 (Hannum, 2012). Tahapan transformasi adalah: penginfeksian, ko-kultivasi, dan recovery. Transformasi menggunakan eksplan $\mathrm{K}$. alvarezii $0,5 \mathrm{~cm}$; dilukai menggunakan jarum steril, kemudian direndam dalam media infeksi yang berisi A. tumefaciens LB-4404 dan $100 \mu \mathrm{M}$ asetosiringon selama 30 menit dengan penggoyangan. Eksplan dikeringkan dengan tisu steril dan dipindahkan ke media ko-kultivasi (media PES dan $100 \mu \mathrm{M}$ asetosiringon) selama tiga hari di ruang gelap. Eksplan hasil ko-kultivasi dicuci dengan cefotaxim 200 mg/L, dibilas dengan air laut steril sebanyak tiga kali. Eksplan dikeringkan di atas tisu steril, kemudian dipindahkan ke media recovery (PES tanpa asetosiringon) selama tujuh hari, kemudian dikultur pada media seleksi yang terdiri atas air laut steril dengan PES dan hygromycin 
$10 \mathrm{mg} / \mathrm{L}$ selama 14 hari. Setelah seleksi, eksplan dipindahkan ke media pemulihan selama 14 hari (Triana et al., 2016).

\section{Regenerasi dan Perbanyakan Rumput Laut Hasil Transgenik}

Eksplan hasil transformasi gen MaSOD dan eksplan tanpa transformasi non-transgenik (kontrol) ditumbuhkan pada media PES hingga menjadi tanaman muda (planlet) mengacu pada metode Sulistiani et al. (2012); Reddy et al. (2003); dan Wu et al. (2006). Eksplan dikultur pada dua tahapan regenerasi (keduanya dilakukan secara aseptik dan in vitro), yaitu: 1) kultur cair pada botol kultur volume $200 \mathrm{~mL}$ yang diletakkan pada shaker goyang selama pemeliharaan, menggunakan media kultur PES. Setiap botol diisi 20 eksplan, selama pemeliharaan dilakukan pergantian media setiap satu minggu. Kemudian dilanjutkan dengan aklimatisasi pada botol kultur dengan volume satu liter yang diletakkan pada 'culture chamber' dan diberi aerasi dengan jumlah eksplan masing-masing 100 eksplan/botol. Selanjutnya aklimatisasi dilakukan pada bak resirkulasi dengan volume $50 \mathrm{~L}$ yang dilengkapi dengan aerasi jumlah plantet hingga 300 eksplan pada setiap bak.

Dalam rangka optimasi media pemeliharaan dilakukan melalui seleksi pupuk antara lain pupuk PES, Grund, Conwy, dan SSW sebagai kontrol, dengan salinitas 20, 25, 30, 35, dan $40 \mathrm{~g} / \mathrm{L}$. Selanjutnya kisaran $\mathrm{pH}$ yang digunakan yaitu $4,5,6,7$, dan 8 . Intensitas cahaya berkisar antara 500-2.000 lux dengan photopheriod terang dan gelap 8:16; 12:12; dan 16:8. Untuk merangsang pertumbuhan eksplan dilakukan pemeliharaan dengan penambahan hormon tumbuh IAA dan BAP dengan beberapa perbandingan 1:1, 1:2, dan 2:1. Penelitian dilakukan menggunakan rancangan acak dengan lima ulangan untuk ke- 6 parameter yang secara bertahap untuk mengurangi bias pada pengamatan masing-masing parameter. Pengamatan dilakukan selama delapan minggu dengan interval satu minggu meliputi sintasan dan laju pertumbuhan. Data yang diperoleh dianalisis menggunakan software statistik versi 3.0 pada $\mathrm{P}=0,05$.

\section{Identifikasi Eksplan Transgenik}

Sebanyak $0,1 \mathrm{~g}$ tunas putatif yang tumbuh setelah pemeliharaan pada bak resirkulasi, diisolasi DNA menggunakan metode Wattier et al. (2000). DNA hasil isolasi selanjutnya dianalisis PCR dengan menggunakan primer MmSOD-F1 (5'-ATG GTGAAGGCTGTGGTTGT$3^{\prime}$ ) dan MmSOD-R2 (5'-CATCTCCAACGGTGACATTG3') (Hannum, 2012). Campuran reaksi yang digunakan adalah $100 \mathrm{ng}$ DNA genom; 0,5 $\mu \mathrm{L}$ masing-masing primer Foward dan reverse ( $10 \mathrm{pmol} / \mu \mathrm{L}) ; 2 \mu \mathrm{L} 1 \mathrm{x}$ bufer
PCR; $2 \mu \mathrm{L}$ dNTPmix; 0,2 $\mu \mathrm{L}$ Tag Polymerase dan ditambah dengan $\mathrm{ddH}_{2} \mathrm{O}$ hingga volume total reaksi menjadi $20 \mu \mathrm{L}$. Analisis dilakukan dengan kondisi PCR: pra PCR $95^{\circ} \mathrm{C}$, lima menit; denaturasi $94^{\circ} \mathrm{C}$, 30 detik; penempelan primer $60^{\circ} \mathrm{C}, 30$ detik; pemanjangan $72^{\circ} \mathrm{C}$, 30 detik; dan reaksi dilakukan sebanyak 30 siklus; dan diakhiri dengan pasca PCR $20^{\circ} \mathrm{C}$ selama 10 menit. Hasil PCR dielektroforesis menggunakan $1 \%$ gel agarosa pada 100 volt selama 28 menit. Gel divisualisasi di atas UV transluminator setelah diwarnai dengan gel red.

\section{HASIL DAN BAHASAN}

Regenerasi rumput laut $K$. alvarezii hasil transformasi gen MaSOD dan rumput laut nontransgenik pada media kultur air laut steril, dan air laut steril yang diperkaya dengan pupuk provasoli enrich seawater (PES), Grund dan Conwy memperlihatkan sintasan berbeda (Gambar 1).

Pada rumput laut $\mathrm{K}$. alvarezii hasil transformasi gen MaSOD memperlihatkan sintasan paling tinggi (94\%), yaitu pada media yang diperkaya dengan pupuk PES, namun tidak berbeda nyata dengan media yang diperkaya dengan pupuk Grund $(80 \%$, berbeda nyata dengan SSW $(30 \%)$, dan media yang diperkaya dengan Conwy $(25 \%$ ( $(P<0,05)$. Pada rumput laut K. alvarezii non-transgenik sintasan yang paling tinggi pada media yang diperkaya dengan pupuk Grund ( $86 \%$ namun tidak berbeda dengan media yang diperkaya dengan pupuk PES $(75 \%$, berbeda nyata dengan SSW $(20 \%)$ dan pupuk Conwy (35\% (Gambar 1). Dari hasil yang diperoleh memperlihatkan adanya perbedaan kebutuhan nutrien dari eksplan rumput laut K. alvarezii hasil transformasi gen MaSOD dan rumput laut nontransgenik, pada transformasi sebelumnya antara lain pada transformasi gen $\mathrm{MaMt}$, dan lisozim sintasan yang paling optimal dan cenderung lebih baik pada media PES (Suryati et al., 2014). Hal ini kemungkinan terjadi karena adanya proses adaptasi selama di laborato rium menggunakan media PES selama proses transformasi gen pada rumput laut K. alvarezii mulai pada tahap mediasi hingga pada proses recoveri sehingga eksplan teradaptasi pada kondisi yang sama. Selain itu, juga disebabkan dari kebutuhan nutrien pada rumput laut dapat dipenuhi oleh nutrien yang berada pada media yang diperkaya dengan PES dan Grund, karena eksplan yang digunakan memang diadaptasi pada media dengan pupuk yang sama sehingga dapat tumbuh dengan baik.

Salinitas merupakan faktor pembatas pada sintasan rumput laut pada umumnya, khususnya pada eksplan rumput laut hasil transformasi. Toleransi kemampuan hidup rumput laut $K$. alvarezii berkisar pada salinitas 20-40 g/L, namun sintasan eksplan transgenik yang tertinggi diperoleh pada salinitas $30 \mathrm{~g} / \mathrm{L}$, berbeda nyata 


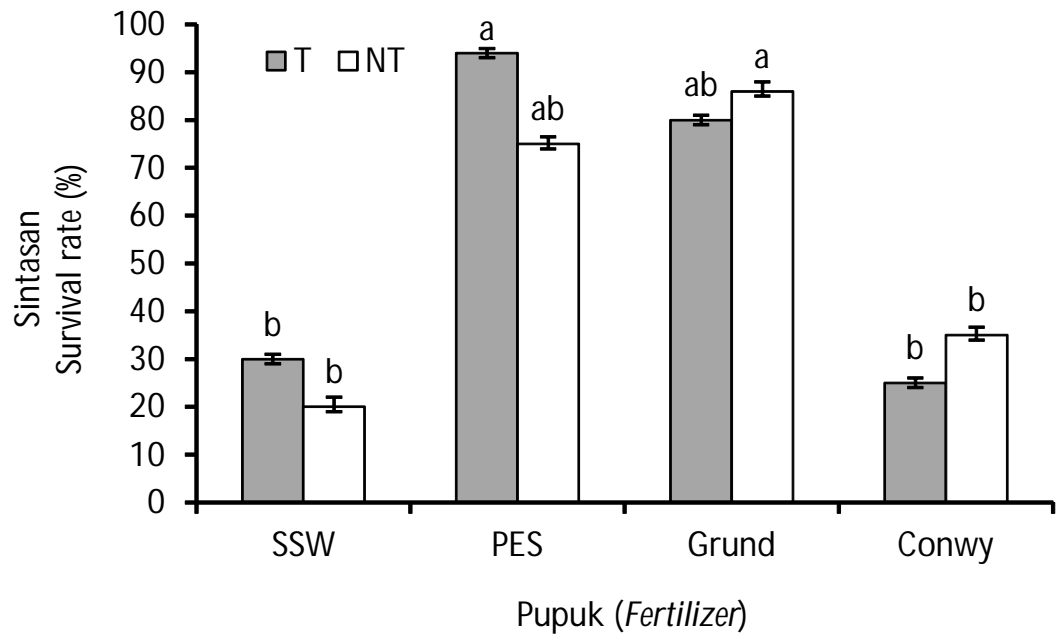

Gambar 1. Sintasan eksplan rumput laut Kappaphycus alvarezii yang diintroduksi dengan gen MaSOD (T), dan K. alvarezii non-transgenik (NT) pada media yang diperkaya dengan pupuk berbeda (Keterangan: SSW (steril sea water); PES (provasoli enrich seawater); Grund, dan Conwy)

Figure 1. Survival rate of seaweed K. alvarezii explant introduced with M ASOD geneand non-transgenic seaweed complemented with various fertilizers (note: $T=$ Transgenic; NT = non-transgenic) (Note: SSW (steril sea water), PES (provasoli enrich seawater); Grund, and Conwy)

dengan salinitas 20 dan $40 \mathrm{~g} / \mathrm{L}$, namun tidak berbeda nyata dengan 25 dan $35 \mathrm{~g} / \mathrm{L}$, sedangkan pada eksplan non-transgenik tertinggi pada $30 \mathrm{~g} / \mathrm{L}$ tidak berbeda dengan $35 \mathrm{~g} / \mathrm{L}$, berbeda dengan 20, 25, dan $40 \mathrm{~g} / \mathrm{L}$ (Gambar 2).

Hal ini sangat erat dengan fisiologi penyerapan dan sirkulasi nutrien pada rumput laut sehingga pada salinitas yang lebih rendah maupun tinggi akan mengakibatkan kematian pada rumput laut. Penyakit ice-ice sering kali terjadi karena adanya perubahan salinitas yang drastis biasanya pada musim pancaroba atau peralihan musim penghujan ke musim kering atau sebaliknya, di samping pengaruh dari kondisi lingkungan baik fisika, kimia, maupun secara biologi.

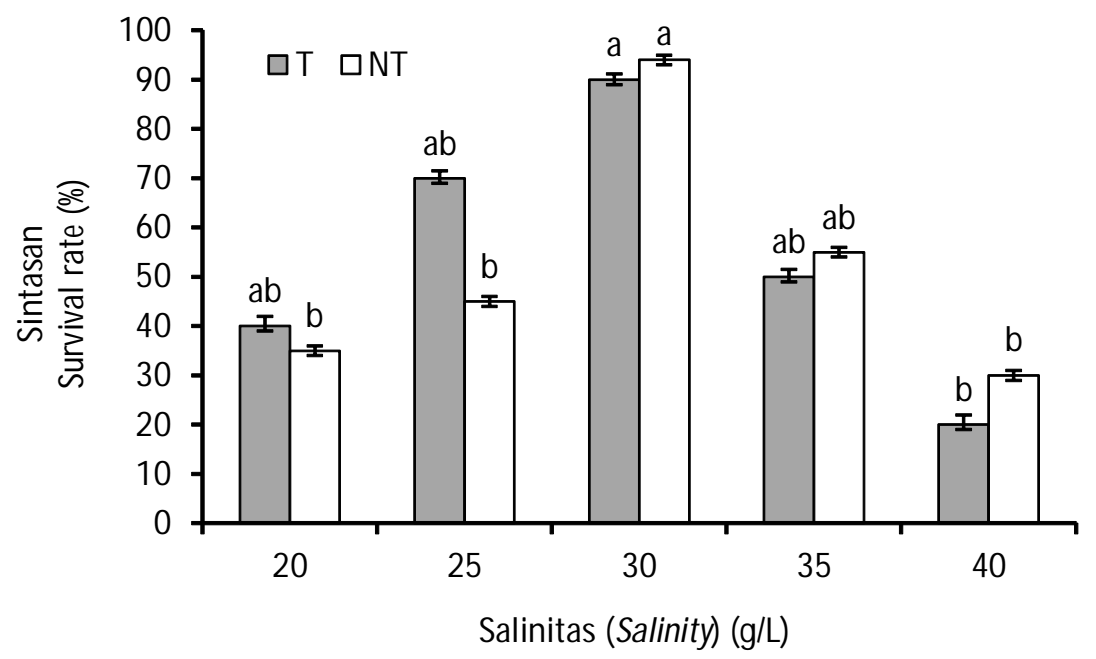

Gambar 2. Sintasan eksplan rumput laut Kappaphycus alvarezii yang diintroduksi genMaSOD dan rumput laut non-transgenik yang dipelihara pada salinitas yang berbeda (Keterangan: $\mathrm{T}=$ transgenik; NT= non-transgenik)

Figure 2. Survival rate of seaweed Kappaphycus alvarezii explant introduced with MaSOD gene and non-transgenic seaweed cultivated in various salinity conditions (Note: $T=$ transgenic; NT= non-transgenic) 
Pada salinitas $30 \mathrm{~g} / \mathrm{L}$ memperlihatkan sintasan paling tinggi baik pada rumput laut transgenik maupun nontrasgenik, hal ini berhubungan dengan proses kesetimbangan senyawa kimia di dalam air laut, yang erat hubungannya dengan sistem osmosa dan penyerapan nutrien tersebut melalui dinding sel rumput laut (Romimohtarto \& Juwana, 2002).

pH pada media kultur merupakan salah satu faktor penentu keberhasilan pada pemeliharaan rumput laut $\mathrm{K}$. alvarezii baik di laboratorium maupun di lapangan, karena penyerapan nutrien dari media tergantung dari derajat keasaman dari lingkungan yang ada dan akan terjadi keseimbangan dalam penyerapan. Hasil pengamatan $\mathrm{pH}$ pada media pemeliharaan $\mathrm{K}$. alvarezii di laboratorium diperlihatkan pada Gambar 3.

Pada rumput laut $\mathrm{K}$. alvarezii yang hidup di laut kisaran $\mathrm{pH}$ yang dapat diterima bisa mencapai pH: 9, namun pada pemeliharaan rumput laut hasil transformasi gen MaSOD dan non-transgenik di laboratorium memperlihatkan respons yang agak berbeda, memperlihatkan sintasan yang paling tinggi pada pH dengan kisaran 6-8 (Gambar 3). Pada rumput laut transgenik sintasan yang paling tinggi pada $\mathrm{pH} 6$ (96\%) dan 8 (85\%) tidak berbeda dengan pH $5(50 \%)$ dan $6(65 \%)$, tapi berbeda nyata dengan $\mathrm{pH} 4(15 \%)$. Sedangkan pada rumput laut non-transgenik sintasan paling tinggi pada $\mathrm{pH}$ 6-7 (85\%90\%) namun tidak berbeda dengan $\mathrm{pH} 8$ (55\%). Perbedaan ini kemungkinan karena adanya proses adaptasi pada kondisi media kultur selama pemeliharaan di laboratorium, serta kondisi rumput laut setelah transformasi gen MaSOD yang menyebabkan lebih toleran terhadap perubahan $\mathrm{pH}$ pada media. Hal ini berbeda dengan $\mathrm{pH}$ optimum pada rumput laut hasil transformasi gen karaginan yang menunjukkan $\mathrm{pH}$ optimum pada $\mathrm{pH}=6$ dengan sintasan mencapai $85 \%$ (Suryati et al., 2015).

Intensitas cahaya diperlukan untuk fotosintesa pada tumbuhan termasuk pada rumput laut $\mathrm{K}$. alvarezii. Pada rumput laut hasil transformasi gen MaSOD kondisi sintasan yang paling tinggi pada $1.500 \mathrm{lux}(80 \%$ tidak berbeda nyata dengan 1.000 lux $(50 \%)$, tapi berbeda nyata dengan 500 lux (35\%) dan 2.000 lux (25\%). Demikian juga pada rumput laut non-transgenik memperlihatkan sintasan paling tinggi pada intensitas 1.500 lux (76\%), namun berbeda nyata dengan intensitas 500 lux, 1.000 lux, dan 2.000 lux (Gambar 4). Terlihat pada rumput laut transgenik MaSOD, memperlihatkan pertumbuhan bibit yang cukup bagus dibandingkan dengan rumput non-transgenik kisaran intensitas cahaya pada rumput laut transgenik lebih luas dibandingkan dengan rumput laut non-transgenik. Sehingga rumput laut hasil transformasi gen MaSOD masih mampu bertahan hidup pada kisaran intensitas tersebut, sedangkan pada rumput laut non-transgenik lebih mudah terjadi kematian pada eksplan. Sangat berbeda dengan kondisi budidaya di laut penetrasi cahaya bisa mencapai 3.000 lux namun peningkatan suhu di laut kemungkinan lebih konstan, serta ada penetrasi dari lingkungan sekitar sehingga rumput laut yang dibudidayakan masih dapat bertahan hidup pada kondisi seperti itu.

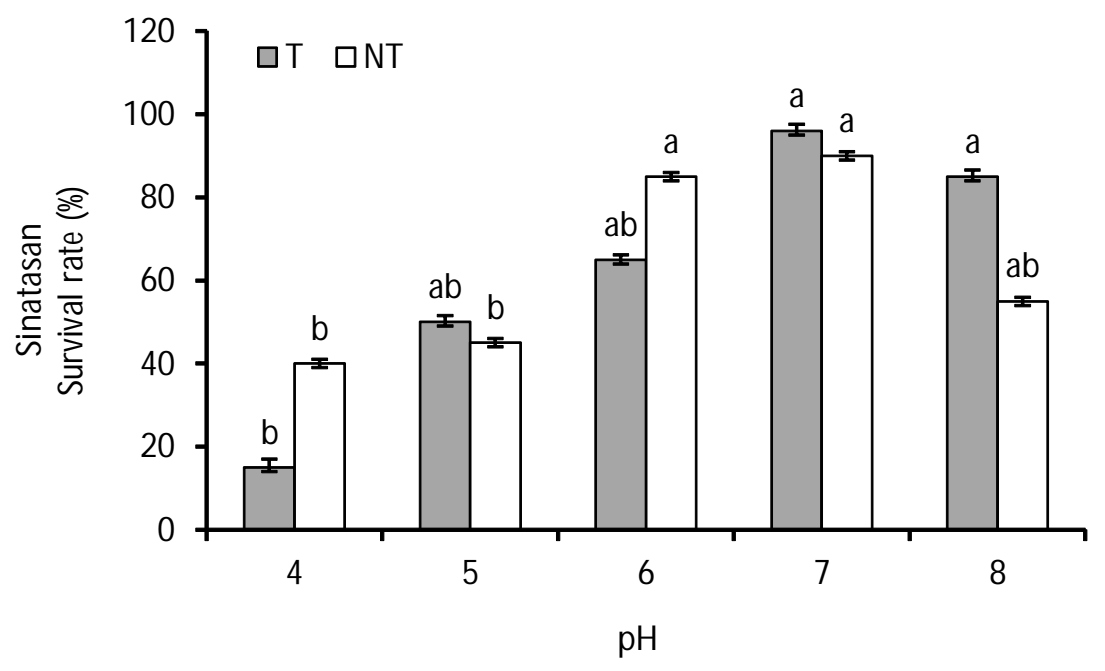

Gambar 3. Sintasan eksplan rumput laut K. alvarezii yang diintroduksi dengan gen MaSOD dan rumput laut non-transgenik yang dipelihara pada media kultur dengan $\mathrm{pH}$ yang berbeda (Keterangan: $\mathrm{T}=$ transgenik; NT= non-transgenik)

Figure 3. Survival rate of seaweed $\mathbf{K}$. alvarezii explant introduced with MaSOD gene and nontransgenic seaweed cultivated in various $\mathrm{pH}$ conditions (Note: $\mathrm{T}=$ transgenic; $\mathrm{NT}=$ nontransgenic) 


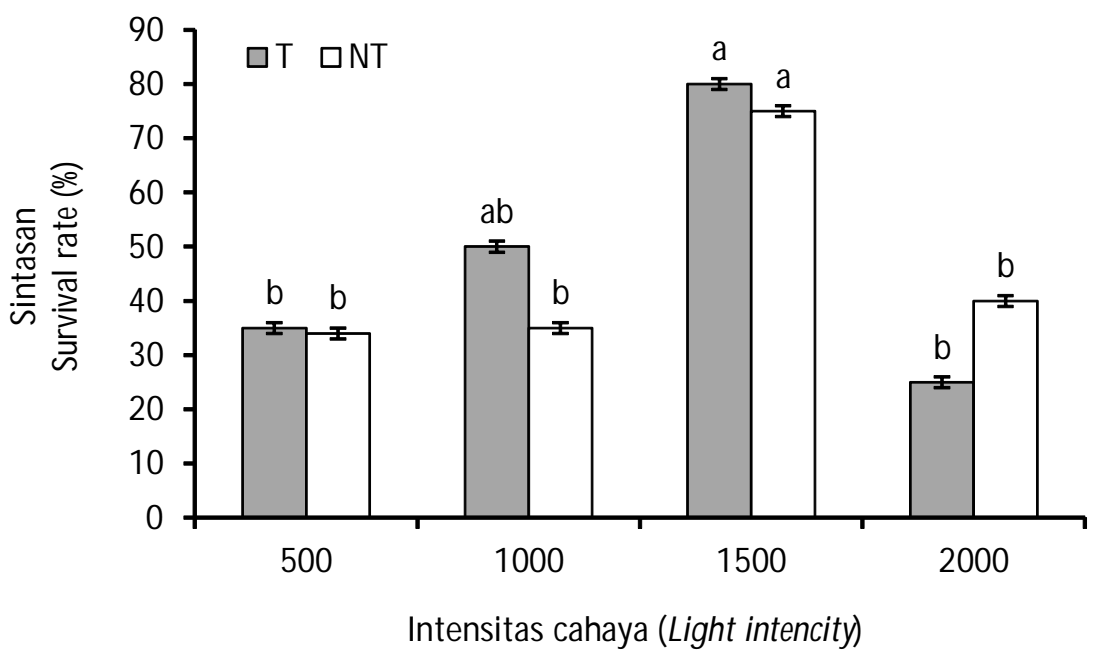

Gambar 4. Sintasan eksplan rumput laut K. alvarezii yang diintroduksi dengan gen MaSOD dan rumput laut non-transgenik yang dipelihara dengan penetrasi cahaya yang berbeda (Keterangan: $\mathrm{T}=$ transgenik; NT = non-transgenik)

Figure 4. Survival rate of seaweed $\mathbf{K}$. alvarezii explant introduced with MaSOD gene and nontransgenic seaweed cultivated with various light intensity conditions (Note: T = transgenic; $\mathrm{NT}=$ non-transgenic)

Penetrasi cahaya pada budidaya rumput laut $\mathrm{K}$. alvarezii di laboratorium sangat diperlukan dalam rangka membantu proses fotosintesis pada rumput laut yang dipelihara. Proses fotosintesis pada terdapat pada tumbuhan hijau termasuk rumput laut bersifat autotrof yakni bisa menyusun makanannya sendiri. Melalui thalus rumput laut menyerap molekul karbon dioksida juga air dalam rangka menghasilkan gula dan juga oksigen. Kedua senyawa tersebut kemudian akan digunakan sebagai penyokong pertumbuhannnya (Romimohtarto \& Juwana, 2002).

Adapun persamaan reaksi yang terjadi dalam proses fotosintesis adalah sebagai berikut:

$$
6 \mathrm{H}_{2} \mathrm{O}+6 \mathrm{CO}_{2}+\text { cahaya } \rightarrow \mathrm{C}_{6} \mathrm{H}_{12} \mathrm{O}_{6} \text { (glukosa) }+6 \mathrm{O}_{2}
$$

Tumbuhan yang melakukan proses fotosintesis memerlukan bantuan cahaya matahari. Mereka mampu menyerap cahaya tersebut sebab mereka memiliki zat hijau daun atau klorofil. Cahaya matahari selanjutnya akan melewati lapisan epidermis yang tanpa warna kemudian melaju menuju mesofil. Proses fotosintesis ini terdiri atas dua rangkaian reaksi yakni reaksi terang dan juga reaksi gelap. Dinamakan reaksi terang sebab prosesnya membutuhkan cahaya. Dalam proses fotosintesis, reaksi terang merupakan proses yang pada akhirnya menghasilkan ATP juga NADPH2. Dalam reaksi ini diperlukan molekul air. Fotosintesis dimulai pada saat cahaya mulai mengionisasi molekul klorofil dan kemudian terjadi pelepasan elektron. Pada tumbuhan sendiri, reaksi biokimia ini akan terjadi siklus calvin di mana karbondioksida akan diikat dengan tujuan membentuk ribose dan lebih lanjut akan menjadi glukosa. Reaksi ini tidak bergantung pada ada atau tidaknya cahaya matahari. Proses fotosintesis pada rumput laut dapat berlangsung dengan laju maksimal jika unsur-unsur pendukungnya terpenuhi yakni antara lain: cahaya, konsentrasi karbondioksida, suhu, kadar air (Romimohtarto et al., 2002).

Proses fotosintesis pada rumput laut, selain tergantung pada intensitas cahayajuga tergantung pada lamanya pemaparan, serta rasio terang dan gelap cahaya yang digunakan. Sintasan eksplan rumput laut hasil transformasi gen M ASOD yang paling tinggi pada rasio terang gelap $L: D=12: 12(84 \%)$ sama dengan dengan perlakuan $L: D=16: 8(80 \%$, berbeda dengan perlakuan $L: D=8: 12(20 \%$, demikian juga pada rumput laut non-transgenik sintasan paling tinggi pada perlakuan $\mathrm{L}: \mathrm{D}=12: 12(80 \%$, namun tidak berbeda nyata dengan perlakuan $L: D=16: 8(50 \%$, dan berbeda nyata dengan perlakuan $\mathrm{L}: \mathrm{D}=8: 16$ (40\% (Gambar 5).

Dalam proses fotosintesis, reaksi terang merupakan proses yang pada akhirnya menghasilkan ATP juga NADPH2. Dalam rekasi ini diperlukan molekul air. Proses reaksi terang dimulai dengan menangkap foton yang dilakukan oleh pigmen klorofil yang berperan sebagai antena. Pada thalus rumput laut, cahaya akan diserap melalui molekul klorofil dan kemudian dikumpulkan pada pusat-pusat reaksi. 


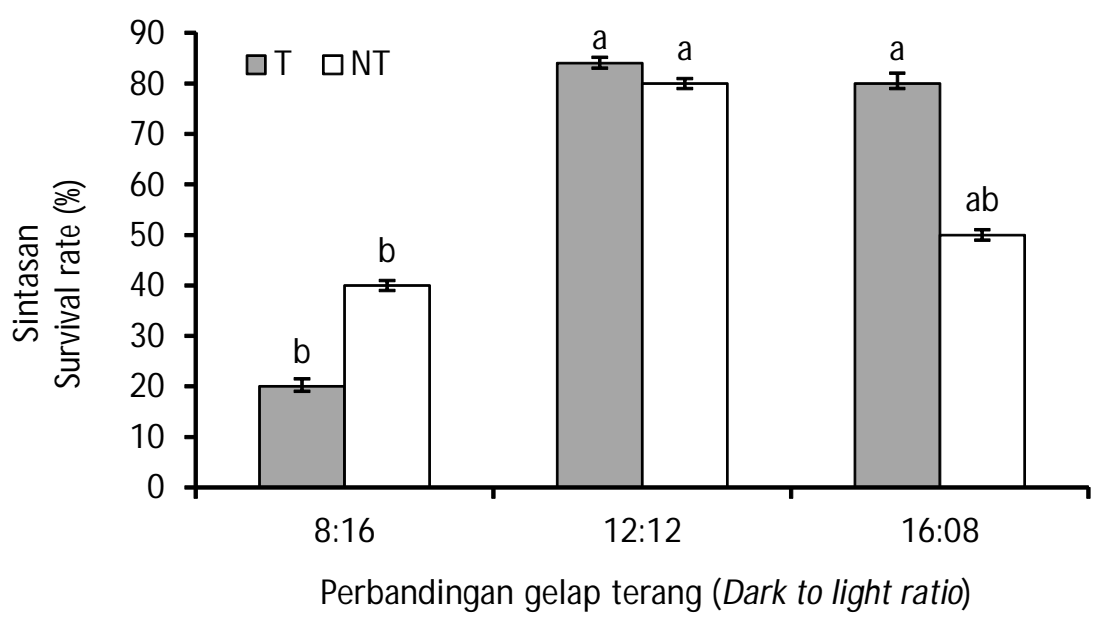

Gambar 5. Sintasan eksplan rumput laut Kappaphycus alvarezii yang diintroduksi dengan gen MaSOD dan rumput laut nontransgenik dengan perbandingan terang dan gelap yang berbeda (Keterangan: $\mathrm{T}=$ transgenik; NT= non-transgenik)

Figure 5. Survival rate of seaweed Kappaphycus alvarezii explant introduced with MaSOD gene and non-transgenic seaweed with various dark to light ratios (Note: $\mathrm{T}=$ transgenic; $\mathrm{NT}=$ non-transgenic)

Fotosintesis dimulai pada saat cahaya mulai mengionisasi molekul klorofil dan kemudian terjadi pelepasan elektron. Sementara itu, apa yang dimaksud dengan reaksi gelap adalah proses di mana ATP dan juga NADPH yang dihasilkan dalam proses sebelumnya kemudian menghasilkan sejumlah proses atau reaksi biokimia. Reaksi biokimia ini merupakan siklus calvin di mana karbon dioksida akan diikat dengan tujuan membentuk ribose dan lebih lanjut akan menjadi glukosa, namun reaksi ini tidak bergantung pada cahaya matahari (Romimohtarto et al., 2002). Pada rumput laut hasil transformasi gen MaSOD sintasannya lebih baik pada rasio 16:8, dibandingkan pada rasio 8:16 hal ini erat hubungnnya dengan proses transfer elektron pada protosintesis, di mana pada gen MaSOD memiliki ko-enzim yang mampu melakukan transfer elektron lebih baik dibandingkan dengan rumput laut non-transgenik.

Pengaruh ZPT pada pemeliharaan rumput laut $\mathrm{K}$. alvarezii diintroduksi dengan gen MaSOD yang di laboratorium memberikan respons yang positif terhadap pertumbuhan dan sintasan eksplan ZPT yang digunakan antara lain dari golongan auxin dan sitokinin yaitu IAA dan BAP yang di campur dalam beberapa perbandingan yaitu kombinasi IAA dan BAP dengan perbandingan 1:1, 1:2, dan 2:1 (Gambar 6).

Untuk memacu pertumbuhan tunas pada kultur jaringan rumput laut K. alvarezii dilakukan pada media PES yang diperkaya dengan penambahan ZPT antara lain dari golongan auksin dan sitokinin yaitu kombinasi IAA dengan BAP dapat meningkatkan kemampuan untuk bertumbuh dan beregenerasi (Suryati \& Mulyaningrum, 2009). Hasil analisis memperlihatkan sintasan rumput laut $K$. alvarezii yang diintroduksi gen MaSOD yang paling baik yaitu pada media PES yang diperkaya dengan IAA dan BAP dengan perbandingan $1: 1$, berbeda nyata dengan kontrol, namun tidak berbeda dengan perbandingan $1: 1$, dan 2:1, demikian juga kontrol tidak berbeda nyata dengan perbandingan 1:2 dan 2:1 (Gambar 6). Hal ini berbeda dengan perbanyakan rumput laut hasil transformasi gen karaginan yang optimal pertumbuhannya dengan penambahan ZPT dengan campuran IAA dan BAP dengan perbandingan 2:1 (Suryati et al., 2015).

Pada aklimatisasi rumput laut K. alvarezii yang diintroduksi dengan gen MaSOD dilakukan pada labu kultur yang diletakkan pada kultur chamber, kemudian dilanjutkan pada bak resirkulasi yang dilengkapi dengan aerasi untuk memacu penyerapan nutrien, serta pertumbuhan anakan rumput laut.

\section{Identifikasi Eksplan Transgenik MaSOD}

Hasil analisis PCR untuk konfirmasi rumput laut transgenik disajikan pada Gambar 8. PCR menggunakan primer MmSOD-F1 dan MmSOD-R2 memperlihatkan adanya pita pada 456 pb pada sampel $P$, merupakan sampel positif yang diisolasi dari plasmid, kemudian dari sampel 1, 2, 3, dan 4 merupakan 


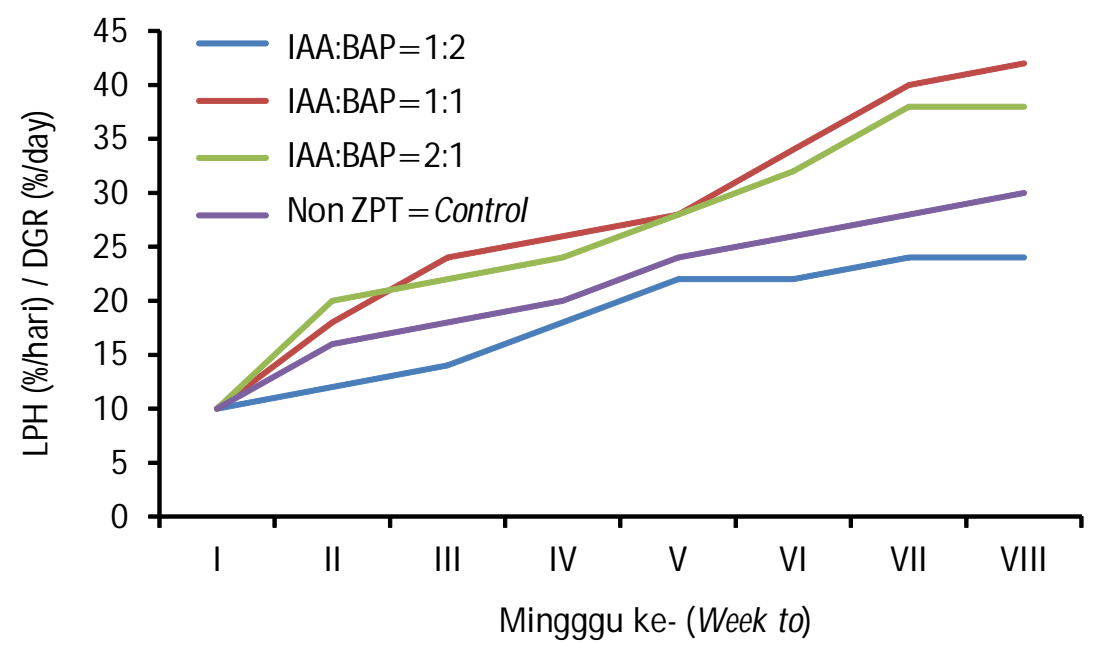

Gambar 6. Laju Pertumbuhan harian (LHP) eksplan rumput laut K.alvarezii hasil transformasi gen MaSOD pada media yang diperkaya ZPT dengan kombinasi IAA dan BAP yang berbeda, serta kontrol= tanpa penambahan ZPT.

Figure 6. Daily growth rate of seaweed K.alvarezii explant transformation with MaSOD gene in enriched media with combination of IAA and BAP are different ratio and not PGR as control
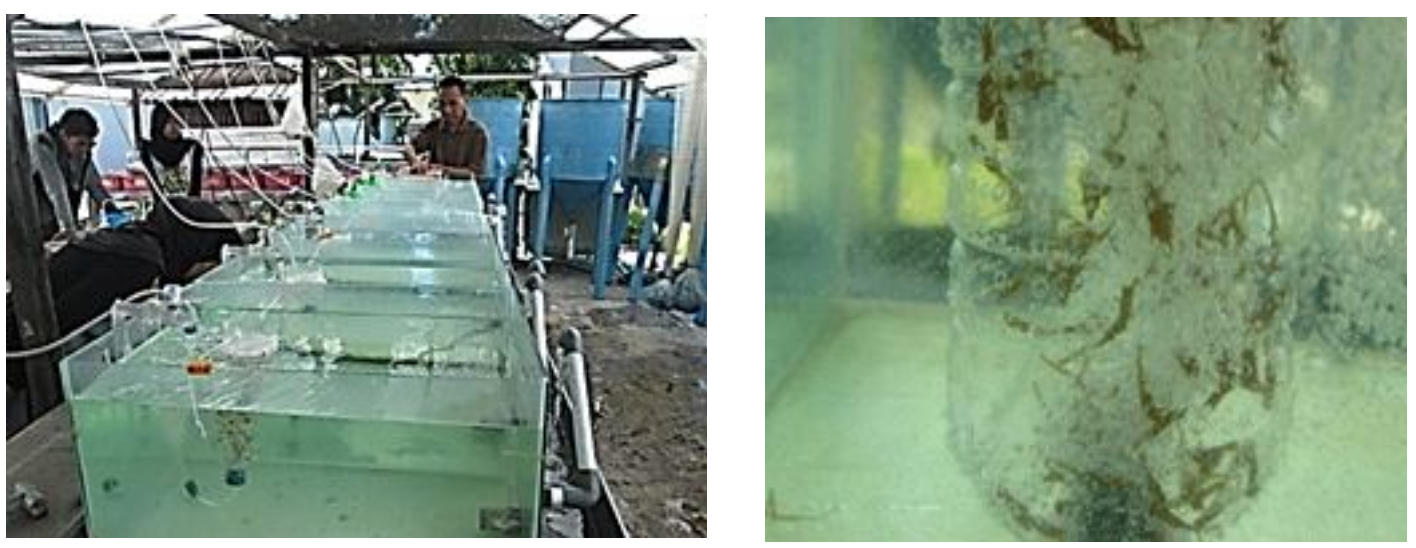

Gambar 7. Aklimatisasi anakan rumput laut K. alvarezii yang diintroduksi dengan gen MaSOD dan rumput laut non-transgenik pada bak resirkulasi yang dilengkapi dengan aerasi

Figure 7. Acclimatization of seaweed $\mathbf{K}$. alvarezii introduced with MaSOD gene and non-transgenic seaweed in recirculation basin complemented with aeration

sampel rumput laut transgenik yang membawa gen MaSOD sebanyak $78 \%$ dari hasil transformasi. Hal ini juga dilakukan pada analisis PCR yang dilakukan oleh Triana et al. (2016) memperlihatkan adanya pita pada 456 bp pada sampel rumput laut transgenik yang membawa gen MaSOD.

\section{KESIMPULAN}

Pada regenerasi rumput laut transgenik MaSOD, memperlihatkan media kultur yang paling baik adalah menggunakan media PES dengan salinitas $30 \mathrm{~g} / \mathrm{L}$, $\mathrm{pH}=7$, penetrasi cahaya 1.500 lux, rasio gelap terang= 12:12, dan komposisi ZPT adalah campuran IAA dan
BAP dengan perbandingan 1:1. Hasil analisis PCR memperlihatkan K. alvarezii transgenik putatif mengandung transgen MaSOD sebanyak 78\%dari hasil transformasi.

\section{UCAPAN TERIMA KASIH}

Penelitian ini dibiayai oleh APBN dari DIPA Loka Penelitian dan Pengembangan Budidaya Rumput Laut (LPPBRL) Gorontalo, Tahun Anggaran 2015. Ucapan terima kasih disampaikan kepada kepala LPPBRL, serta peneliti BPPBAP Maros yang telah membantu kelancaran pelaksanaan penelitian ini. 


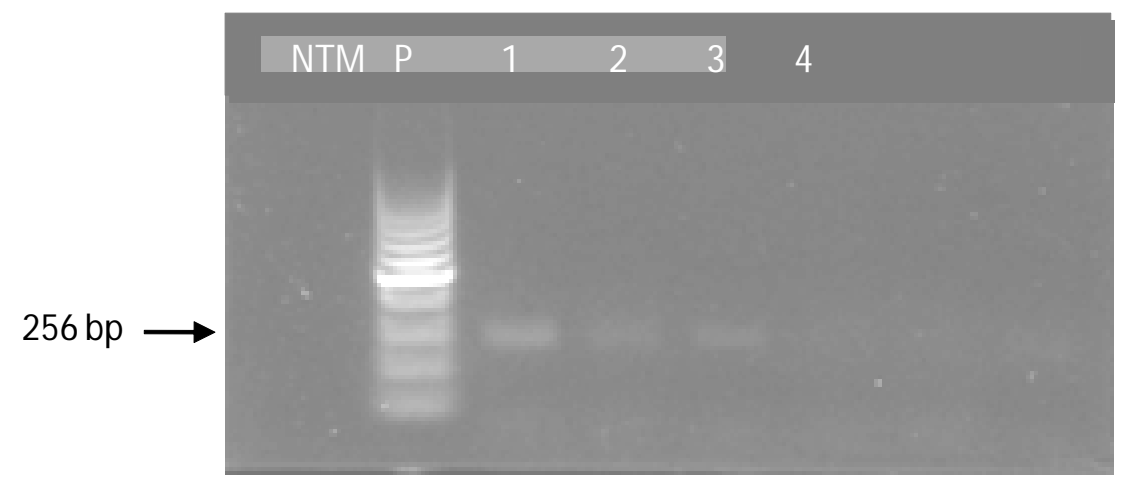

Gambar 8. Hasil elektroforesis produk PCR dengan DNA genom dari rumput laut K. alvarezii hasil transformasi dengan gen MaSOD dan non-transforman. PCR dilakukan dengan primer MmSODF-M mSODR2, NT= non-transgenik, $M=$ marker $1 \mathrm{~kb}$ DNA; $P$ adalah kontrol positif (plasmid pGWB5-M mCU/Zn-SOD); 1-4 = rumput laut transgenik

Figure 8. Electrophoresis result of PCR product with DNA genome from seaweed $\mathbf{K}$. alvarezii transformed with MaSOD gene and non-transformant. PCR was conducted with primary MmSODF-M mSODR2, NT = non-transgenic, $M=$ marker $1 \mathrm{~kb} D N A ; P$ is positive control (plasmid pGWB5-M mCU/Zn-SOD); 1-4= transgenic seaweed

\section{DAFTAR ACUAN}

Cheney, D.P. (2000). Agrobacterium-mediated genetic transformation of multicellular marine algae, resultant strains and their products. international classes. Northeastern University (Huntington Avenue Boston) US. http://ip.com/patfam/en/ 22440221. [tanggal akses 20 September 2012].

Cheng, R., Ruijuan, M.A., Ke, L., Hui, R., Xiangzhi, L., Zhaokai, W., Shanjun, Y., \& Yong, M. (2011). Agrobacterium tumefaciens mediated transformation of marine microalgae Schizochytrium. Micres., 25421, 1-8.

Collen, J.U. (1995). Farming and physiology of the red alage eucheuma gowing commercial importance in East Africa. Ambio., 24, 7-8.

Daud, R.F., Widyastuti, U., Suharsono, Suryati, E., \& Parenrengi, A. (2013). Introduksi gen sitrat sintase ke dalam rumput laut Kappaphyus alvarezii menggunakan Agrobacterium tumefaciens. J. Ris. Akuakultur, 8(2), 201-208.

Food and Agriculture Organization of the United Nations [FAO]. (2010). The State of world fisheries and aquaculture.sales and marketing group ofûce of knowledge exchange. Research and Extension Food and Agriculture Organization of the United Nations Viale delle Terme di Caracalla 00153, Rome. Italy, 218 pp.

Fajriah, U., Suryati, E., Parenrengi, A., Suharsono, \& Widyastuti, U. (2015). Introduksi gen metallothionein tipe II ke dalam rumput laut Kappaphyus alvarezii menggunakan Agrobacterium tumefaciens. J. Ris. Akuakultur, 9(3), 377-385.
Handayani, T., Alimuddin, Widyastuti, U., Suryati, E.., $\&$ Parenrengi A. (2014). Binary vector construction and Agrobacterium tumefaciens-mediated transformation of lysozyme gene in seaweed Kappaphycus alvarezii. Biotropia, 21(2), 80-90.

Hannum, S. (2012). Isolasi, pengklonan, dan analisis ekspresi gen penyandi Copper/Zinc Superoxide Dismutase (CuZn-SOD) dari Melastoma malabathricum L. Disertasi. Sekolah Pascasarjana. Institut Pertanian Bogor. Bogor, $106 \mathrm{hlm}$.

Largo, D.B., Faukami, K., Adachi, M., \& Nhisijima, T. (1997). Direct enumeration of total bacteria from macroalgae by epifluoresecence microscopy asapllied to the flashy red algae Kappaphycus alvarezii and Glacilaria spp. (Rhodophyta). J. Phycol., 33, 554-557.

Mamboya, F.A. (2007). Heavy metal contamination and toxicity: studies of macroalgae from the Tanzania Coast. Stockholm University Library. Stockholm, U.S.,: p. 1-48. ISBN 91-7155-374-6. http:// www. diva-portal.org/smash/get/diva2:197112/ FULLTEXT01.pdf.

Rajamuddin, M.A.L., Alimuddin, Widyastuti, U., \& Faizal, I. (2014). Evaluation of different promoters driving the GFP reporter gene in seaweed Kappaphycus alvarezii. Indonesian J. Biotechnology, 19(2), 129-135.

Rajamuddin, M.A.L., Alimuddin, Widyastuti, U., \& Harris, E. (2016). Transformation of kappa (ê)carrageenase gene from Pseudoalteromonas in seaweed Kappaphycus alvarezii [Doty]. Pak. J. Biotechnol., 13(3), 157-163. 
Reddy, C.R.K., Kumar, G.R.K., Siddhanta, A.K., Tewari, A., \& Eswaran, K. (2003). In Vitro somatic embriogenesis and regeneration of somatic embryos from pigmented callus of Kappaphycus alvarezii (Doty) Doty (Rhodophyta, Gigartinales). J. Phycol., 39, 610-616.

Romimohtarto, K., \& Juwana, S. (2002). Biologi laut: ilmu pengetahuan tentang biologi laut. Penerbit Djambatan. Jakarta, $540 \mathrm{hlm}$.

Sulistiani. E., Soelistyowati, D., Alimuddin, \& Yani, S.A. (2012). Introduction and filaments regeneration from callus of cottonii seaweed (Kappaphycus alvarezii (Doty) collection from Natuna Island, Riau Islands Province. Biotropia, 19(2), 103-114.

Suryati, E., \& Mulyaningum, S.R.H. (2009). Regenerasi rumput laut Kappaphycus alvarezii (Doty) melalui induksi kalus dan embrio dengan penambahan hormon perangsang tumbuh secara In vitro. J. Ris. Akuakultur, 4(1), 39-45.

Suryati, E., Daud, R.F., Widyastuti, U., Tenriulo, A., \& Parenrengi, A. (2014). Regenerasi rumput laut Kappaphycus alvarezii hasil transformasi gen sitrat sintase menggunakan Agrobacterium tumefacien secara in Vitro. J. Ris. Akuakultur, 9(2), 169-178.

Suryati, E., Tenriulo, A., Rajamuddin, M.A.L., \& Widyastuti, U. (2015). Regenerasi rumput laut hasil introdulsi gen karaginan pada rumput laut Kappaphycus alvarezii menggunakan media kultur yang berbeda dengan kondisi optimal. Prosiding Forum Inovasi Teknologi Akuakultur, hlm. 1-7.
Triana, S.H., Alimuddin, Widyastuti, U., Suharsono, Suryati, E., \& Parenrengi, A. (2016). The method of Agrobacterium tumefaciens-mediated $\mathrm{MmCu} / \mathrm{Zn}$ SOD gene transformation in the red seaweed Kappaphycus alvarezii. Pakistan J. Biotechnology (in press).

Vairappan, C.S. (2006). Seasonal occurancences of epiphytic algae on the comercially cultivated red algae Kappaphycus alvarezii (Soliriciae, Gigartinales, Rhodophyta). J. Applied Phycol., 18, 611-617.

Wattier, R.A., Prodöhl, P.A., \& Maggs, C.A. (2000). DNA Isolation protocol for red seaweed (Rodophyta). Journal Plan Biology Moleculer, 18(3), 275-281.

Wu, Y.F., Chen, Y., Liang, X.M., \& Wang, X.Z. (2006). An experimental assessment of the factors influencing Agrobacterium-mediated transformation in tomato. Russian J. Plant Physiology, 53(2), 252-256.

Yulianto, K., \& Mira, S. (2009). Budidaya makro alga Kappaphycus alvarezii (Doty) secara vertikal dan gejala penyakit "ice-ice" di perairan Pulau Pari. Dalam Juwana, S., \& Riyatno. Oseanologi dan Limnologi di Indonesia Edisi 35(3). Jakarta [ID]. Pusat Penelitian Oceanografi dan Penelitian Limnologi LIPI. hIm. 325-334. ISSN 0125-9830. http:// www.limnologi.lipi.go.id/limnologi/doc/public/ 3._Naskah_Kresno__Mira.pdf. 